\title{
PENERAPAN MODEL PEMBELAJARAN KOOPERATIF TIPE MIND \\ MAPPING (PETA PEMIKIRAN) DENGAN MEDIA GAMBAR \\ UNTUK MEMPERBAIKI PROSES BELAJAR SISWA KELAS X TGB \\ PROGRAM KEAHLIAN BANGUNAN PADA MATA PELAJARAN \\ KONSTRUKSI BANGUNAN DI SMK N 2 SURAKARTA \\ TAHUN PELAJARAN 2016/2017
}

\author{
Prisilia Dhika Wiranti ${ }^{1}$, Rima Sri Agustin ${ }^{2}$, Sutrisno $^{3}$ \\ Email: prisiliawiranti@gmail.com
}

\begin{abstract}
Abstrak : Penelitian ini bertujuan untuk : (1) mengetahui perbaikan proses belajar siswa dan (2) mengetahui peningkatan hasil tes evaluasi belajar siswa kelas $\mathrm{X}$ TGB Program Keahlian Bangunan pada mata pelajaran Konstruksi Bangunan di SMK N 2 Surakarta melalui penerapan model pembelajaran kooperatif tipe mind mapping.Penelitian ini merupakan Penelitian Tindakan Kelas yang dilaksanakan dalam 2 siklus. Siklus I dengan perencanaan tindakan, pelaksanaan tindakan, observasi, dan refleksi untuk tindakan siklus II. Subyek penelitian ini adalah siswa kelas X TGB SMK Negeri 2 Surakarta tahun pelajaran 2016/2017 pada mata pelajaran Konstruksi Bangunan. Data diperoleh dari observasi, wawancara, catatan lapangan, dan tes. Teknik analisis data menggunakan teknik analisis interaktif.Hasil penelitian menunjukkan bahwa diperoleh penerapan model pembelajaran kooperatif tipe mind mapping (peta pemikiran) dengan media gambar dapat : (1) memperbaiki proses belajar dan (2) meningkatkan hasil tes evaluasi belajar siswa kelas X TGB SMK Negeri 2 Surakarta tahun pelajaran 2016/2017 pada mata pelajaran Konstruksi Bangunan. Siswa menjadi lebih baik dalam proses belajar meliputi aktivitas belajar, partisipasi siswa dalam diskusi dan proses belajar dengan metode mind mapping. Hasil tes evaluasi belajar siswa mengalami kenaikan persentase sebesar $9,88 \%$ dari pra siklus sampai siklus I,dan dari siklus I ke siklus II naik 68,74\%, pada aktivitas belajar siswa, partisipasi siswa dan proses belajar dengan metode mind mapping sudah mencapai predikat Baik dan Sangat Baik.
\end{abstract}

Kata Kunci : Model pembelajaran kooperatif, Mind Mapping, Proses Belajar, Hasil tes evaluasi belajar

\footnotetext{
${ }^{1}$ Mahasiswa Pendidikan Teknik Bangunan Fakultas Keguruan dan Ilmu Pendidikan

${ }_{3}^{2}$ Pengajar Pendidikan Teknik Bangunan Fakultas Keguruan dan Ilmu Pendidikan

${ }^{3}$ Pengajar Pendidikan Teknik Bangunan Fakultas Keguruan dan Ilmu Pendidikan
} 


\begin{abstract}
This study aims to: (1) know the improvement of student learning process and (2) know the improvement of the result of the evaluation test of the students' learning of class X TGB Building skills Program in Building Construction lesson at SMK N 2 Surakarta through the implementation of cooperative learning model of mind mapping type. This research is a Classroom Action Research which was conducted in 2 cycles. Cycle I with action planning, action execution, observation, and reflection for action cycle II. The subjects of this study were students of class X TGB SMK Negeri 2 Surakarta 2016/2017 lesson year on the subject of Building Construction. Data were obtained from observations, interviews, field notes, and tests. Data analysis techniques using interactive analysis techniques. The result of the research shows that the implementation of cooperative learning model of mind mapping type with the image media can: (1) improve the learning process and (2) improve the result of the evaluation test of class X student of TGB SMK Negeri 2 Surakarta 2016/2017 at Subjects of Building Construction. Students become better in learning process include learning activity, student participation in discussion and learning process with mind mapping method. The result of evaluation test of student learning has increased percentage equal to 9,88\% from pre cycle to cycle I, and from cycle I to cycle II 68,74\%, on student learning activity, student participation and learning process with mind mapping method has reached predicate Good and Very Good.
\end{abstract}

Keywords: Cooperative learning model, Mind Mapping, Learning Process, Result of evaluation test

\title{
PENDAHULUAN
}

Konstruksi Bangunan merupakan salah satu mata siswa kelas $\mathrm{X}$ Sekolah Menengah Kejuruan (SMK) Program Keahlian Bangunan jurusan Teknik Gambar Bangunan (TGB). Konstruksi Bangunan merupakan prasyarat untuk kelompok mata pelajaran kompetensi kejuruan. Berdasarkan pengalaman peneliti saat mengampu mata pelajaran konstruksi bangunan dalam Praktik Pengalaman Lapangan di SMK N 2 Surakarta selama kurang lebih mencapai waktu 3 bulan, standar kompetensi pada mata pelajaran ini, peserta didik diharapkan mampu memahami, menjelaskan, serta menguasai ilmu dasar bahan dan kompenen pada bangunan. Berdasarkan observasi awal yang telah peneliti lakukan pada mata pelajaran konstruksi bangunan siswa kelas X TGB SMK N 2 Surakarta, dapat diketahui keterlibatan guru dalam mengajar siswa hanya menggunakan media power point kemudian siswa membaca dan mencatat satu per satu slide yang ditampilkan. Model pembelajaran yang digunakan oleh guru tidak menggunakan media (manual) yaitu menjelaskan materi pembelajaran di 
papan tulis, sehingga materi kurang tergambar dengan jelas. Hal ini menyebabkan siswa tidak mudah dalam mereview kembali materi pembelajaran karena tidak ada media yang membantu siswa mengingat dan menghafal serta memahami setiap materi pembelajaran yang diberikan oleh guru dari awal sampai akhir. Oleh karena itu dalam proses pembelajaran diperlukan penerapan model yang mampu mendorong siswa untuk terlibat lebih aktif dan tidak hanya mencatat materi yang diberikan, diharapkan pula siswa dapat memahami dan mengingat serta menguasai setiap detail materinya. Salah satu model pembelajaran yang melibatkan peran serta siswa dalam adalah pembelajaran kooperatif. Pembelajaran kooperatif merupakan salah satu alternatif dalam proses pembelajaran, karena di dalam pembelajaran kooperatif dapat meningkatkan kemampuan siswa dalam bekerja sama atau bekerja kelompok dalam memecahkan masalah dan berfikir kritis serta dapat saling bertukar informasi sehingga dapat memperbaiki proses belajar siswa. Model pembelajaran ini membagi siswa dalam kelompokkelompok kecil secara heterogen atau berdasar urutan absen. Hal ini memotivasi mereka untuk saling berinteraksi,berdiskusi, berargumentasi dan berorientasi. Dalam rangka meningkatakan proses belajar siswa dengan adanya model pembelajaran kooperatif diharapkan siswa benar-benar dapat menguasai materi yang diberikan oleh guru dan mendapatkan hasil tes evaluasi belajar yang sangat memuaskan karena siswa mampu memahami materi bahkan dengan adanya pembelajaran kooperatif siswa dapat berbagi info mengenai materi konstruksi bangunan. Selain melatih cara berfikir siswa yang berbeda dalam hal melakukan pembelajaran di kelas dengan pembelajaran kooperatif siswa dapat melatih tanggung jawab dalam hal kerja sama kelompok serta kekompakan dalam hal diskusi.

Model pembelajaran kooperatif terdapat macam-macam tipenya. Salah satu tipe model pembelajaran kooperatif yaitu tipe Mind Mapping. Model pembelajaran ini diperkenalkan oleh Toni Buzan. Model ini baik digunakan untuk pengetahuan awal siswa atau untuk menemukan alternatif jawaban. Dengan adanya model pembelajaran kooperatif tipe mind mapping diharapkan siswa dapat 
mengekspresikan diri mereka dan dapat berpendapat dalam diskusi kelompok mengenai materi yang telah diberikan oleh guru. Siswa juga bisa mewarnai gambar mind mapping yang telah mereka buat sehingga siswa selalu ada kegiatan dalam setiap kegiatan belajar mengajar, selalu aktif bertanya jika ada hal yang belum dipahami. Untuk melengkapi model pembelajaran kooperatif tipe Mind Mapping ini peneliti menggunakan media gambar mengenai materi kontruksi bangunan yang terkait dengan jenis dan fungsi struktur bangunan, dan dikarenakan dengan gambar siswa dapat menyalurkan ide-ide abstrak ke dalam bentuk lebih nyata seperti halnya dengan menggambar apa yang mereka sukai yang dituangkan dalam bentuk mind mapping, lebih menarik serta membangkitkan minat dan perhatian siswa, dan diharapkan siswa tidak jenuh dengan hal tersebut dikarenakan waktu yang panjang, dengan materi berupa teori, digunakan tipe metode belajar yang berbeda dan menyenangkan.

Dalam buku Suprijono (2013:54) mengutip pendapat Panitz bahwa pembelajaran kooperatif (cooperative learning) adalah konsep yang lebih luas meliputi semua jenis kerja kelompok termasuk bentuk-bentuk yang lebih dipimpin oleh guru atau diarahkan oleh guru. Secara umum pembelajaran kooperatif dianggap lebih diarahkan oleh guru, di mana guru menetapkan tugas dan pertanyaan-pertanyaan serta menyediakan bahan-bahan dan informasi yang dirancang untuk membantu peserta didik menyelesaikan masalah yang dimaksud. Dengan pernyataan di atas maka model pembelajaran mind mapping merupakan suatu penyajian materi yang dikemas dalam bentuk pemetaan pikiran, bahwa materi yang disajikan akan dipusatkan pada pemikiran siswa.

Sani (2013:240) juga mengatakan "mind maping adalah suatu diagram yang digunakan untuk mempresentasikan katakata, ide-ide, tugas-tugas, ataupun suatu yang lainnya yang dikaitkan dan disusun mengelilingi kata kunci ide utama.

Berhubungan dengan pernyataan di atas bahwa mind mapping dapat disajikan dengan diagram, yang akan berfungsi sebagai perantara untuk mempresentasikan materi berupa katakata, ide-ide, serta tugas-tugas dengan cara mengaitkan dan menyusun mengelilingi kata kunci ide utama.

Smaldino, dkk dalam buku Anitah (2009a:5) mengatakan bahwa media 
adalah suatu alat komunikasi dan sumber informasi. Berasal dari bahasa Latin yang berarti "antara" menunjuk pada segala sesuatu yang membawa informasi antara sumber dan penerima pesan. Dikatakan media pembelajaran, bila segala sesuatu tersebut membawakan pesan untuk suatu tujuan pembelajaran.

Menurut Gerlach \& Ely dalam buku Anitah (2009a:5) mengatakan bahwa gambar tidak hanya bernilai seribu bahasa, tetapi juga seribu tahun atau seribu mil. Melalui gambar dapat ditunjukkan kepada pebelajar suatu tempat, orang, dan segala sesuatu dari daerah yang jauh dari jangkauan pengalaman pebelajar sendiri. Gambar juga dapat memberikan gambaran dari waktu yang telah lalu atau potret (gambaran) masa yang akan datang. dan sumber informasi. Berasal dari bahasa Latin yang berarti "antara" menunjuk pada segala sesuatu yang membawa informasi antara sumber dan penerima pesan. Dikatakan media pembelajaran, bila segala sesuatu tersebut membawakan pesan untuk suatu tujuan pembelajaran.

\section{METODOLOGI PENELITIAN}

Penelitian ini dilaksanakan di SMK N 2 Surakarta yang beralamat di Jln. Adi
Sucipto No.33, Surakarta, Jawa Tengah, Indonesia telp (0271) 714901. Kampus SMK N 2 Surakarta sekarang menempati lahan seluas $23.150 \mathrm{~m}^{2}$ yang meliputi : ruang bengkel, ruang teori, perpustakaan, ruang perkantoran, ruang laboratorium, sarana olah raga dan tempat ibadah. Letak sekolah tersebut $\pm 500 \mathrm{~m}$ sebelah barat Stadion Manahan Surakarta.

Lokasi ini dipilih peneliti sebagai tempat penelitian karena di lokasi tersebut dikarenakan peneliti melakukan Praktik Pengalaman Lapangan (PPL) dan ketika melihat serta mengobservasi di lokasi tersebut ditemukan kualitas proses pembelajaran yang berupa partisipasi siswa saat mata pelajaran Konstruksi Bangunan di SMK N 2 Surakarta masih belum maksimal.

Waktu peneitian dilaksanakan mulai bulan Januari 2017 - Agustus 2017 yang meliputi perijinan sampai dengan selesainya penelitian ini.

Peneliti dalam Penelitian Tindakan Kelas menggunakan metode Kualitatif. Penelitian kualitatif ini sering disebut metode penelitian naturalistik karena penelitiannya dilakukan pada kondisi yang alamiah (natural setting).Dalam penelitian kualitatif, peneliti merupakan instrumen kunci, teknik pengumpulan 
data menggunakan teknik triangulasi (penggabungan), analisis data bersifat induktif, dan hasil penelitian lebih menekankan pada makna ( Lusi dan Nggili, 2013 : 44). Penelitian ini terdapat dua subjek penelitian, yaitu guru dan siswa kelas X TGB Program Keahlian Bangunan di SMK N 2 Surakarta, semester II tahun pelajaran 2016/2017. Jumlah siswa yang diteliti sebanyak 32 siswa, 24 siswa laki-laki dan 8 siswa perempuan.

Data kuantitatif diwujudkan dengan hasil belajar Konstruksi Bangunan yang diperoleh siswa sebelum dan setelah pelaksanaan pembelajaran dengan model pembelajaran mind mapping. Data kualitatif ini diperoleh dari hasil observasi dengan menggunakan lembar observasi aktivitas ,keterampilan guru, aktivitas siswa, catatan lapangan serta wawancara dalam pembelajaran Konstruksi Bangunan. Sumber data diperoleh dari siswa, guru, data dokumen dan catatan lapangan. Teknik pengumpulan data berupa pedoman observasi, pedoman wawancara, kajian dokumen dan tes. Untuk menjaga kevalidan dalam penelitian ini, digunakan teknik triangulasi, yaitu teknik pemeriksaan data yang memanfaatkan sesuatu yang lain diluar data itu. Triangulasi dalam penelitian ini adalah triangulasi metode. Jenis triangulasi ini dilakukan dengan mengumpulkan data sejenis tetapi dengan menggunakan teknik pengumpulan data yang berbeda, dan bahkan lebih jelas untuk diusahakan mengarah pada sumber data yang sama untuk menguji kebenaran informasinya. Dalam penelitian ini peneliti menggunakan metode pengumpulan data yang berupa tes hasil tindakan, obsevasi selama kegiatan belajar mengajar berlangsung dan wawancara. Teknik analisis yang dilakukan sejak awal sampai akhir kegiatan pengumpulan data. Data-data dari hasil penelitian dilapangan diolah dan dianalisis secara analisis interaktif. Analisis mempunyai tiga kegiatan yaitu : reduksi data, penyajian data, penarikan kesimpulan atau verifikasi. Tiga jenis Kegiatan analisis dan kegiatan pengumpulan data merupakan proses siklus dan interaktif. Pada waktu pengumpulan data, peneliti selalu membuat reduksi data dan sajian data ini harus disusun pada waktu peneliti sudah mendapatkan sejumlah data yang diperlukan dalam penelitian. Reduksi 
data yaitu proses pemilihan, pemusatan perhatian pada penyederhanaan dan transformasi data kasar yang muncul dari catatan-catatan yang tertulis di lapangan. Saat pengumpulan data berakhir, peneliti mulai melakukan usaha untuk menarik kesimpulan yang dilakukan secara bertahap. Dengan demikian analisis data kualitatif dalam penelitian tindakan ini dilakukan semenjak tindakan- tindakan dilaksanakan. Indikator yang dinilai yaitu aktivitas belajar siswa, partisipasi siswa, proses belajar siswa dengan mind mapping,hasil tes evaluasi siswa. Prosedur penelitian yaitu ada siklus dan siklus II. Masing-masing siklus terdiri dari : perencanaan tindakan, pelaksanaan tindakan, pengamatan dan refleksi.

Tabel 1. Hasil Observasi Pra Siklus

\begin{tabular}{lcccc}
\hline \multicolumn{1}{c}{$\begin{array}{c}\text { Indikator yang } \\
\text { diamati }\end{array}$} & \multicolumn{4}{c}{ Nilai } \\
\cline { 2 - 5 } & $\mathrm{A}$ & $\mathrm{B}$ & $\mathrm{C}$ & $\mathrm{D}$ \\
\hline Mencatat Materi & & 13 & 5 & 7 \\
Keaktifan Bertanya & 0 & 1 & 6 & 25 \\
Memperhatikan Guru & 2 & 21 & 4 & 5 \\
\hline
\end{tabular}

\section{HASIL PENELITIAN DAN \\ PEMBAHASAN}

\section{Pra Siklus}

Pada pra siklus peneliti melakukan observasi dengan mengamati 3 indikator yang berhubungan dengan proses belajar siswa yaitu, mencatat materi, keaktifan bertanya, dan memperhatikan guru. Hal ini dipilih peneliti untuk mengetahui proses belajar pada tahap pra siklus. Untuk lebih jelasnya hasil pra siklus disajikan pada tabel 1 .

Hasil observasi siswa untuk mengetahui keadaan siswa yang sesungguhnya. Melalui observasi awal yang dilakukan di kelas X TGB B SMK Negeri 2 Surakarta pada tanggal 23 Maret 2017 dapat diketahui proses belajar siswa masih rendah, belum banyak yang mendapat nilai Baik (B). Hal ini dikarenakan siswa yang cenderung hanya mencatat saja sesuai dengan power point yang dipresentasikan oleh guru. Dalam indikator mencatat materi yang mendapatkan nilai predikat A hanya 7 siswa dikarenakan catatan siswa yang paling lengkap dan rapi, rapi dalam artian tulisan masih dapat dibaca. 
Data penelitian selain observasi yaitu dengan wawancara yang disertai catatan lapangan, dan terdapat pre-test yang dilaksanakan setelah siswa menerima pembelajaran dari guru mata pelajaran Konstruksi Bangunan. Berdasarkan hasil tes siswa kelas X TGB B mata pelajaran Konstruksi Bangunan maka dapat dilihat pada diagram 5. Pada hasil tes siswa yang tuntas persentasenya $12,5 \%$ dan siswa yang tidak tuntas $87,5 \%$.

\section{Penelitian Siklus I}

Penelitian siklus I dilaksanakan pada hari Kamis, 30 Maret 2017. Kehadiran siswa sebanyak 32 siswa. Berikut data hasil siklus I: Data hasil pengamatan dan predikat siswa untuk aktivitas belajar siswa disajikan gambar 1 .

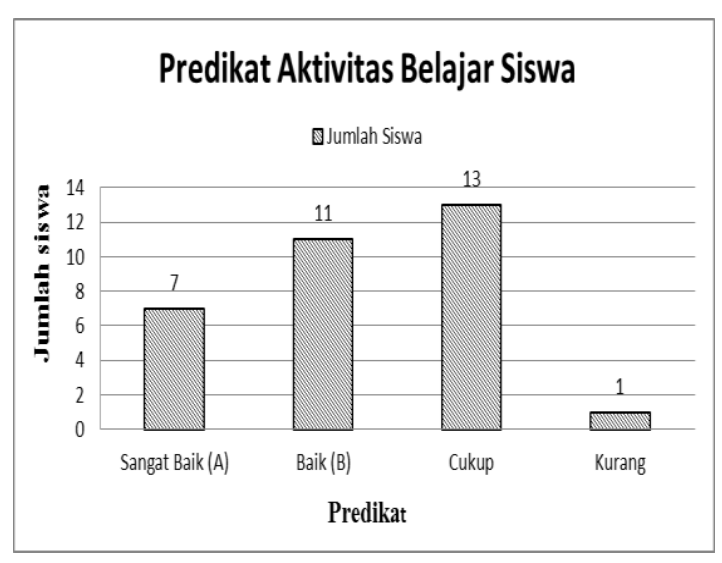

Gambar 1. Diagram predikat aktivitas belajar siswa
Pada gambar 8 diperoleh data bahwa predikat siswa sangat baik diperoleh sejumlah 7 siswa kemudian sejumlah 11 siswa mendapatkan nilai baik. 13 siswa cukup dan 1 siswa yang bernilai kurang. Pada kenyataannya siswa dalam aktivitas belajar memang sedikit meningkat dibanding dengan sebelum adanya tindakan di kelas dengan memberikan model pembelajaran kooperatif tipe mind mapping.

Pada pelaksanaan observasi siklus I peneliti dibantu oleh tim observer mengamati partisipasi siswa dalam diskusi pada proses pembelajaran selama proses pembelajaran berlangsung. Aspek yang diamati meliputi mengajukan pertanyaan, Turut serta memberi komentar,memperhatikan pertanyaan orang lain, mencatat jawaban masalah, memaksakan pendapat. Data hasil pengamatan dan predikat siswa untuk aktivitas belajar siswa disajikan gambar 2. 


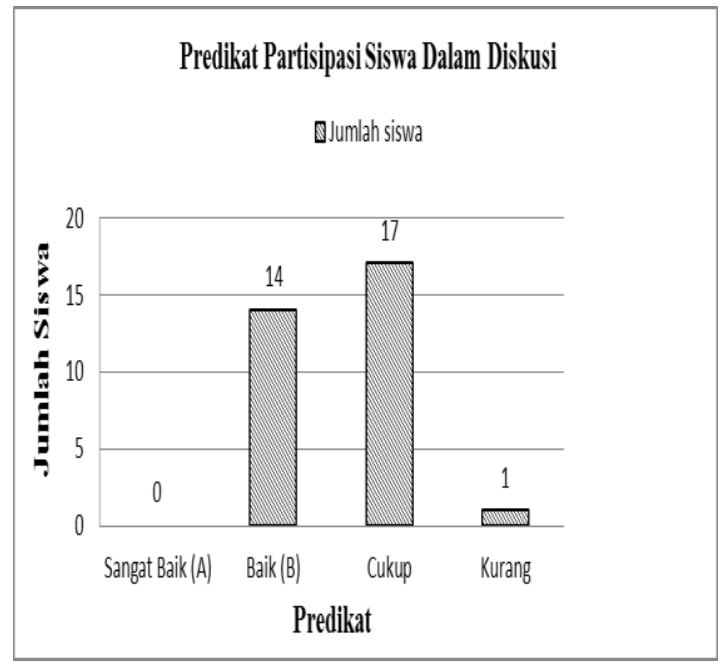

\section{Gambar 2. Diagram Predikat Partisipasi Siswa Dalam Diskusi}

Dalam penilaian ini terdapat 14 siswa mendapat nilai baik, dkarenakan 14 siswa dari kelompok yang berbedabeda inilah yang menunjukkan partisipasi yang baik. Meski tidak mengemukakan pendapat namun, siswa bertanya kepada siswa lain bahkan kepada siswa kelompok lain agar pekerjaan sesuai dengan harapan masing-masing kelompok dan tentunya mendapat nilai yang memuaskan bagi masing-masing kelompok. Sedangkan sebanyak 17 siswa dinilai cukup karena siswa tersebut hanya menggunting dan menempel serta mewarnai tanpa memberikan pendapat ataupun berkomentar tentang pendapat teman sekelompoknya.

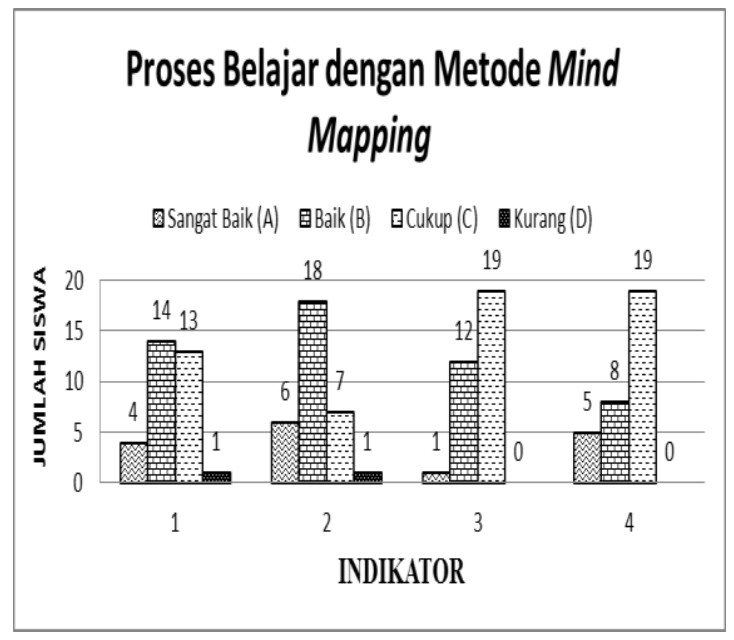

Gambar 3. Diagram Hasil Proses Belajar dengan Merode Mind Mapping

Indikator : 1.Keaktifan siswa, 2. Kerja sama dalam mengerjakan tugas kelompok, 3. Kreativitas dalam membuat mind mapping 4 . Penyampaian Kesimpulan.

Hasil tes belajar siswa diperoleh dari evaluasi pembelajaran pada siklus I terhadap 32 siswa diperoleh data sebagai berikut :

a. Siswa yang tuntas belajar sebanyak 7 siswa $(21,88 \%)$.

b. Siswa yang belum tuntas belajar sebanyak 25 siswa $(78,12 \%)$.

\section{Penelitian Siklus II}

Penelitian siklus II dilaksanakan pada hari Kamis, 27 April 2017. 
Kehadiran siswa sebanyak 32 siswa.

Berikut data hasil siklus I: Pada pelaksanaan observasi siklus II peneliti dibantu oleh tim observer mengamati aktivitas belajar siswa selama proses pembelajaran berlangsung.

Aspek yang diamati meliputi memberikan pendapat, memberikan tanggapan terhadap orang lain, mengerjakan tugas yang diberikan, motivasi dalam mengerjakan tugastugas,toleransi dan mau menerima pendapat siswa lain, tanggung jawab sebagai anggota kelompok. Data hasil pengamatan dan predikat siswa untuk aktivitas belajar siswa disajikan pada gambar 4.

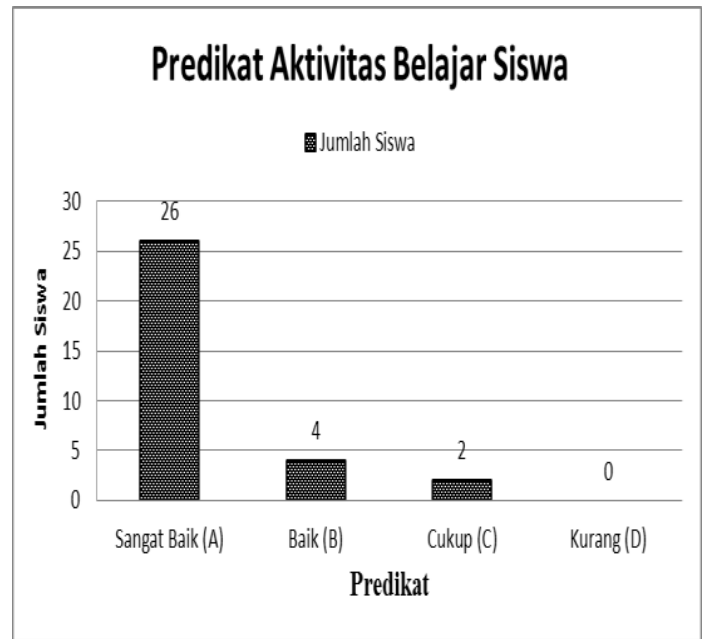

.Gambar 4. Diagram predikat aktivitas belajar siswa
Siswa berjumlah 26 sudah mendapat nilai predikat $A$ hal ini dikarenakan siswa sangat termotivasi untuk lebih baik dalam hal pembuatan mind mapping, dan banyak siswa yang pada siklus I hanya pasif dia mau bekerja dan berpendapat serta menyelesaikan pekerjaan mind mapping nya artinya tanggung jawab sebagai anggota kelompok telah terpenuhi . Sedangakan 4 siswa mendapat nilai Baik hal ini berarti dapat dikatakan 30 siswa dari 32 siswa aktivitas belajar mereka sudah meningkat dikarenakan motivasi, mengajukan pendapat serta tanggung jawab siswa terhadap kelompok. Dan 2 siswa yang lain dinilai cukup.

Pada pelaksanaan observasi siklus II peneliti dibantu oleh tim observer mengamati partisipasi siswa dalam diskusi pada proses pembelajaran selama proses pembelajaran berlangsung. Aspek yang diamati meliputi mengajukan pertanyaan, Turut serta memberi komentar, memperhatikan pertanyaan orang lain, mencatat jawaban masalah, memaksakan pendapat. Data hasil pengamatan dan predikat siswa untuk 
aktivitas belajar siswa disajikan dalam gambar 5.

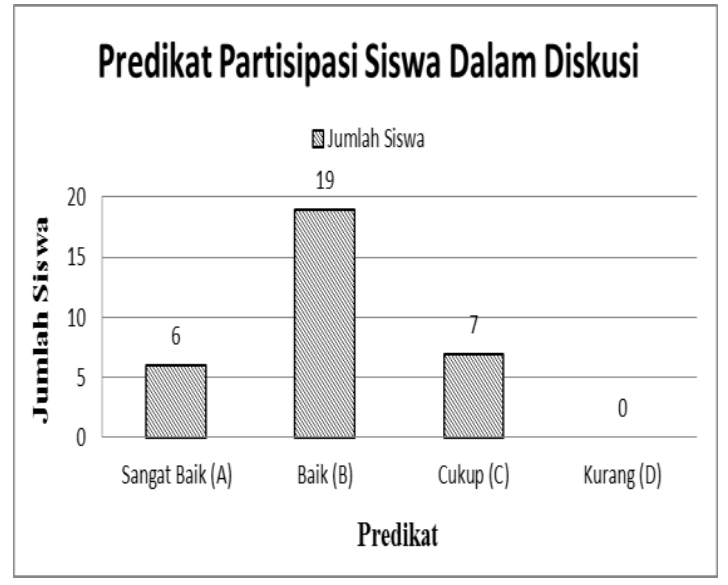

Gambar 5. Diagram Predikat Partisipasi Siswa Dalam Diskusi

Dapat dilihat dari diagram dan tabel bahwa 6 siswa sudah mendapat nilai sangat baik sedangkan 19 siswa bernilai baik. Hal ini dikarenakan saat sebelum diskusi dimulai guru memberikan perlakuan yang berbeda yaitu jika di siklus I siswa cukup memperhatikan guru menerangkan dengan media gambar pada power point namun di siklus II siswa diberikan materi dengan sudah di print, dan siswa tinggal menyimak apa yang ada pada kertas dan pada kertas terdapat gambar yang dapat menjelaskan lebih rinci jenis dan fungsi struktur bangunan jadi dalam kertas dilengkapi gambar serta penjelasan rinci mengenai materi tersebut. Siswa menjadi antusias untuk segera berdiskusi untu membuat mind mapping di siklus II. Kemudian pada siklus II 7 siswa dinilai cukup karena mereka masih cukup dalam berpartisipasi. Ada pula di sini siswa yang pada pra siklus tidak mempunyai catatan, namun pada saat membuat mind mapping, siswa tersebut menjadi pemimpin dalam kelompok diskusi serta yang mengeluarkan ide menggambar dalam pembuatan mind mapping.

Pada kegiatan observasi peneliti mengamati beberapa hal yang terkait dengan metode mind mapping. Data disajikan pada gambar 6

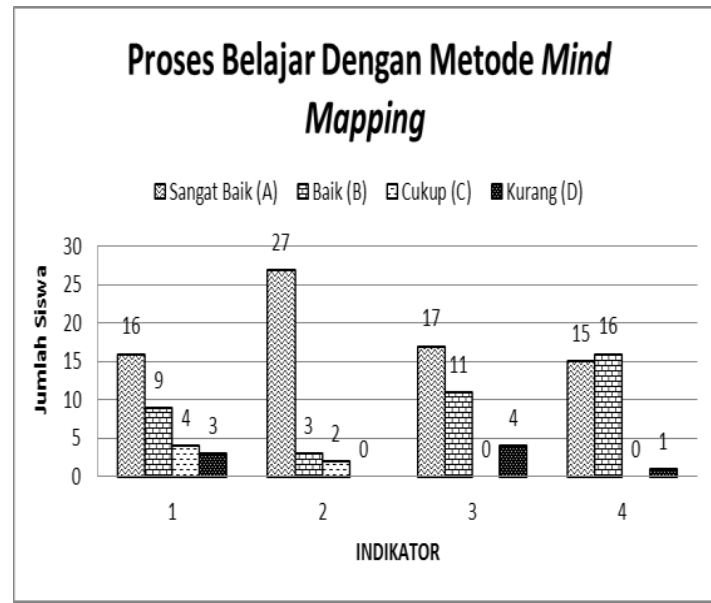

Gambar 6 Diagram Hasil Proses Belajar dengan Merode Mind Mapping 
Hasil tes belajar siswa diperoleh dari evaluasi pembelajaran pada siklus I terhadap 32 siswa diperoleh data sebagai berikut :

a. Siswa yang tuntas belajar sebanyak 29 siswa $(90,62 \%)$.

b. Siswa yang belum tuntas belajar sebanyak 3 siswa $(9,38 \%)$.

\section{Perbandingan Hasil Tindakan}

Pada aktivitas belajar siswa dapat dlihat perbandingannya antara siklus I dan siklus II pada gambar 7.

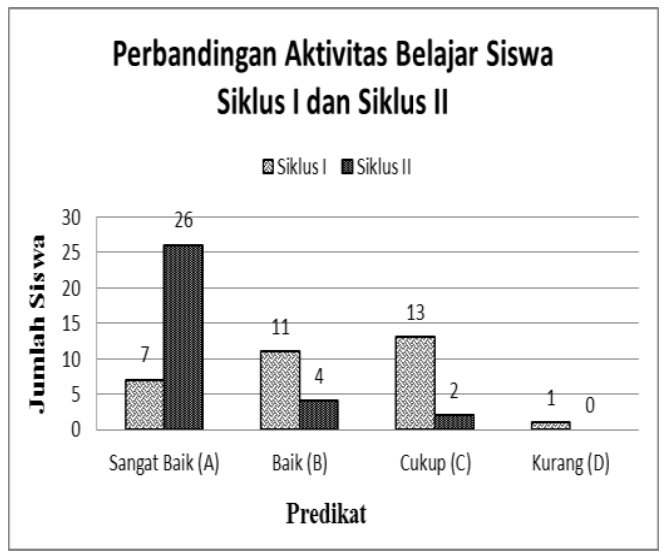

Gambar 7. Diagram Perbandingan Aktivitas Belajar Siswa

Partsipasi siswa dalam Diskusi pada proses pembelajaran dapat dlihat perbandingannya antara siklus I dan siklus II pada gambar 8 .

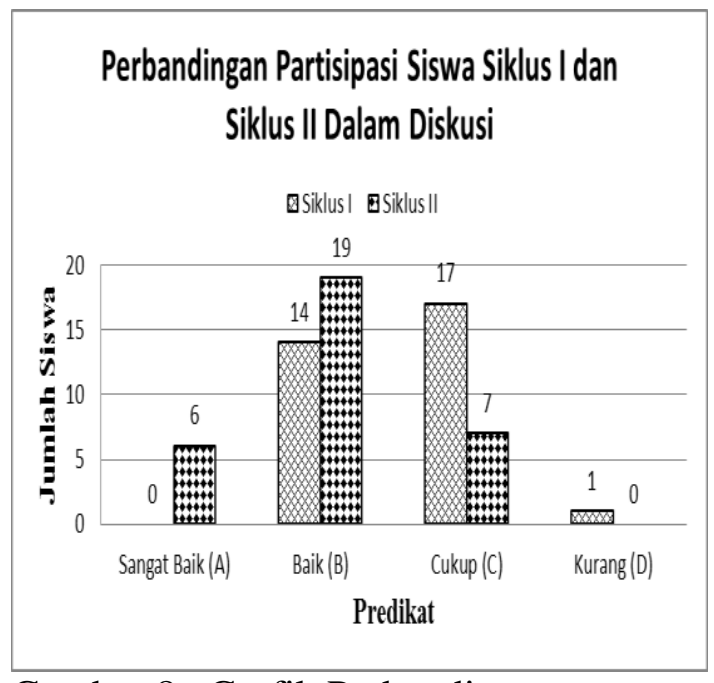

\section{Gambar 8. Grafik Perbandingan Partisipasi Siswa Dalam Diskusi}

Proses Belajar dengan metode Mind Mapping siswa pada dapat dlihat perbandingannya antara siklus I dan siklus II pada gambar 9.

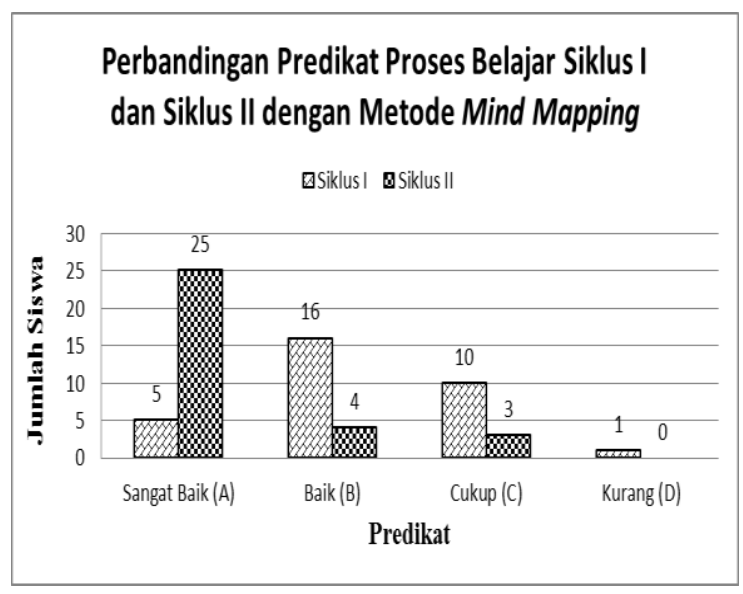

Gambar 9. Diagram Perbandingan Proses Belajar dengan Metode Mind Mapping

Pada Pra siklus, siklus I dan siklus II diperoleh data hasil evaluasi Belajar siswa sebelum mendapat metode Mind 
Mapping dan setelah mendapat metode Mind Mapping dapat dilihat pada gambar 10.

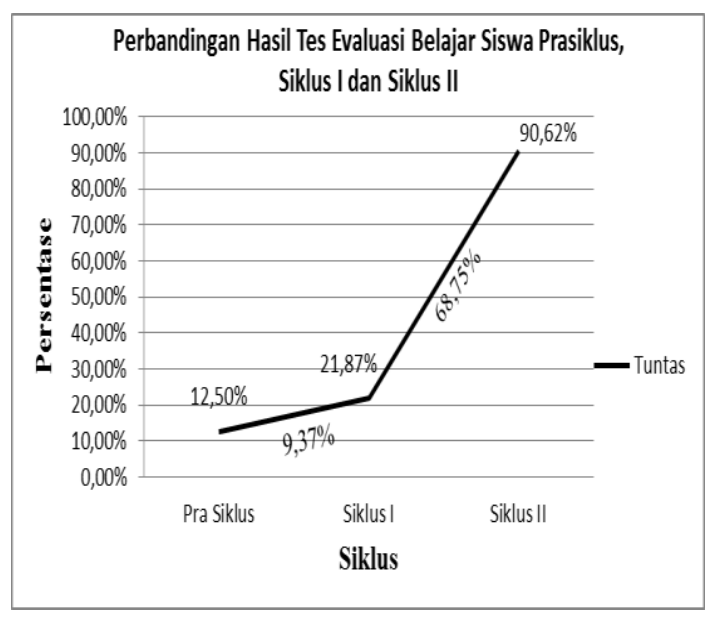

Gambar 10. Grafik Perbandingan Hasil Tes Evaluasi Belajar Siswa

\section{Pembahasan}

Berdasarkan data yang didapat saat penelitian tindakan kelas diperoleh data bahwa penerapan metode pembelajaran mind mapping menjadikan siswa lebih mudah dalam memahami materi. Berdasar pada data yang diperoleh pada saat sebelum dilaksanakan tindakan, diperoleh bahwa keaktifan siswa masih sangat kurang, hal ini diperoleh pada data hanya ada 1 siswa yang aktif bertanya dan menjawab guru saat pembelajaran berlangsung. Kemudian hampir semua siswa mempunyai buku catatan namun hanya 20 anak yang memiliki catatan lengkap dan rapi.

Namun, masih ada 7 siswa yang tidak mempunyai buku catatan, padahal guru memberikan materi selalu dengan media power point lalu siswa mencatat materi yang ada dalam buku catatan. Banyak siswa yang masih pasif dalam kegiatan belajar mengajar, dan tidak menjawab pertanyaan dari guru, namun di saat guru memberikan humor sedikit siswa langsung aktif dalam humor guru, setelah diberi pertanyaan hanya ada 1 siswa yang selalu menjawab, dan yang lain hanya diam. Dari hasil wawancara siswa ketika ditanya mengenai cara menerima pelajaran konstruksi bangunan saat dikelas siswa menjawab dengan mencatat dalam buku catatan.

Pada siklus I yang mendapatkan predikat sangat baik (A) berjumlah 7 siswa sedangkan predikat baik (B) berjumlah 11 siswa, kemudian predikat cukup (C) berjumlah 13 siswa dan yang mendapat predikat kurang (D) yaittu 1 siswa peneliti membuat nilai yang ditargetkan adalah baik(B). Kemudian pada siklus II dilakukan lagi penilaian terhadap aktivitas belajar siswa pada siklus II banyak mengalami peningkatan diperoleh 26 siswa mendapat predikat 
nilai sangat baik (A) dan 4 siswa bernilai baik (B) sedangkan 2 siswa mendapat nilai cukup (C) dan tidak ada siswa yang mendapat nilai kurang (D). Peneliti juga menilai partisipasi siswa dalam diskusi, pada siklus I diperoleh data 14 siswa bernilai B (baik), 17 siswa mendapat nilai $\mathrm{C}$, dan 1 siswa mendapat nilai D. Hasil tes evaluasi siswa peneliti juga menelitinya, hal ini bertujuan untuk mengetahui peningkatan pengetahuan dan pemahaman konsep mengenai materi konstruksi bangunan jenis dan fungsi struktur bangunan. Peningkatan diperoleh sangat signifikan, pada saat pra siklus hanya terdapat 4 siswa yang tuntas jika dipersentase $12,5 \%$ siswa tuntas dan yang tidak tuntas sebanyak 28 siswa atau $87,5 \%$ siswa yang masih dibawah KKM, berdasarkan KKM mata pelajaran Konstruksi Bangunan KKM yaitu 76, artinya saat pra siklus 28 siswa mendapatkan nilai dibawah 76. Sedangkan pada tes evaluasi setelah diadakan tindakan dengan metode mind mapping siswa yang tuntas berjumlah 7 siswa atau 21,88\% siswa tuntas dan yang tidak tuntas sebanyak 25 siswa $(78,12 \%)$. Artinya hanya mengalami peningkatan dari pra siklus ke siklus I sebanyak 9,88 \%. Sedangkan pada siklus II sebanyak 29 siswa mendapat nilai diatas KKM yaitu 90,62\% siswa tuntas sedangkan yang tidak tuntas hanya 9,38\% atau 3 siswa tidak tuntas, sehingga sangat signifikan peningkatan dari siklus I ke siklus II yaitu sebanyak $68,74 \%$ hasil tes evaluasi belajar siswa sudah meningkat.

\section{SIMPULAN,IMPLIKASI,DAN SARAN}

Berdasarkan pada observasi yang telah dilakukan dan penelit memperoleh hasil penelitian pada penerapan metode pembelajaran kooperatif tipe mind mapping dengan media gambar pada siswa X TGB SMK N 2 Surakrarta dapat ditarik simpulan bahwa : 1).Penerapan metode mind mapping dengan media gambar dapat meningkatkan aktivitas belajar siswa dengan jumlah 19 siswa, kemudian pada partisipasi siswa dalam diskusi meningkat 6 siswa dan proses belajar dengan metode mind mapping meningkat sebanyak 20 siswa., 2). persentase peningkatan pra siklus ke siklus I sebanyak 9,88\% dan dari siklus I ke siklus II yaitu sebanyak 68,74\%. 
Hasil penelitian ini dapat digunakan sebagai masukan guru dalam meningkatkan partisipasi dan hasil belajar siswa. Dalam proses pembelajaran terdapat banyak faktor yang mempengaruhi aktivitas belajar siswa, partisipasi siswa,dan proses belajar siswa seperti halnya pemilihan metode pembelajaran siswa dan media yang digunakan yang tepat dan dapat diterapkan kepada semua siswa di kelas. Secara praktis penerapan model pembelajaran kooperatif tipe mind mapping dengan media gambar dapat meningkatkan aktivitas belajar siswa, partisipasi siswa dan terutama pada proses belajar siswa di dalam kelas maupun di luar kelas.

Berkaitan dengan simpulan di atas, maka peneliti dapat mengajukan saransaran sebagai berikut : 1). Memberikan langkah-langkah mind mapping secara runtut dari awal hingga akhir, 2). Pembuatan mind mapping lebih jelas apabila dibuat secara runtut agar mudah dipahami, 3). Seharusnya perlakuan pada setiap siklus harus mendukung pengembangan proses belajar disertai pengembangan media, 4). Pembentukan kelompok supaya lebih efektif dibentuk 2-3 orang setiap kelompok. 


\section{DAFTAR PUSTAKA}

Anitah, S. (2009). Media Pembelajaran. Surakarta : Panitia Sertifikasi Guru Rayon 13 FKIP UNS.

Anitah, S. (2009). Teknologi Pembelajaran. Surakarta : Yuma Pustaka

Aqib, Z. (2013). Model-mode, Media, dan Strategi Pembelajaran Kontekstual (Inovatif). Bandung : Yrama Widya.

Buzan, T. (2013). Buku Pintar Mind Map. Jakarta : Gramedia Pustaka Utama Chaplin (1972) \& (Reber, 1998). Pengertian Contoh dan Macam Proses Belajar. Diperoleh tanggal 4 Januari 2017 dari http://delsajoesafira.blogspo t.co.id/2010/05/pengertiancontoh-dan-macamproses.html?m=1.

Hidayat, (2011). Menyusun Skripsi \& Tesis. Bandung : Informatika Bandung 